\title{
Cystatins, cysteine peptidase inhibitors, as regulators of immune cell cytotoxicity
}

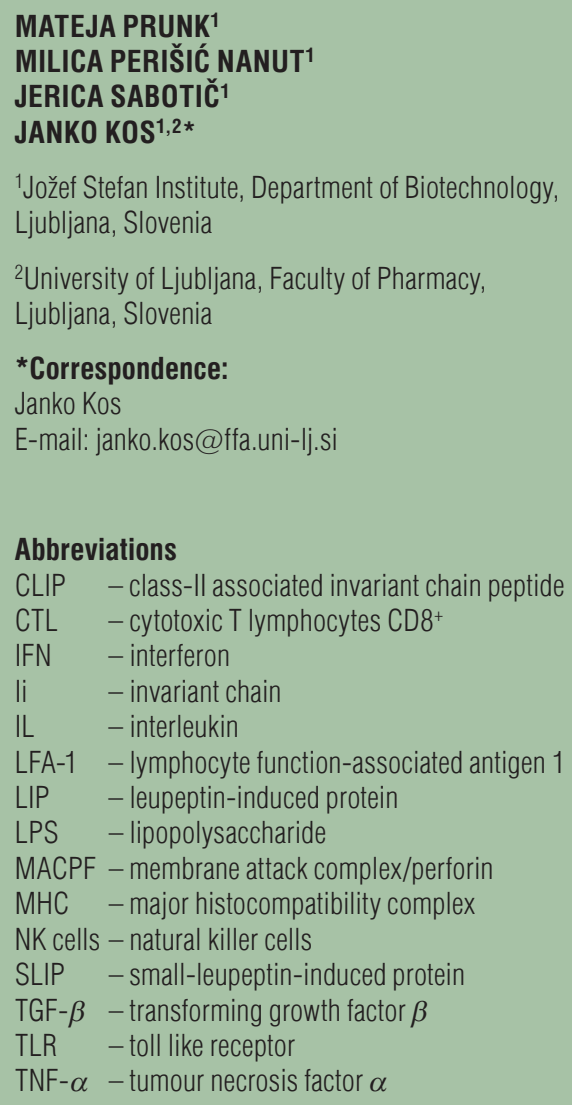

Key words: cystatin; cathepsin; legumain; immune response; cytotoxic cell; granzyme; perforin

Received September 14, 2016.

Revised October 26, 2016.

Accepted October 29, 2016.

\begin{abstract}
Cystatins comprise a superfamily of evolutionarily related proteins, present in all living organisms, from protozoa to mammals. They act as inhibitors of cysteine peptidases although they can also function independently of their inhibitory function. Cysteine cathepsins are implicated in various physiological and pathological processes. In the immune response they are involved in antigen processing and presentation, the cytotoxicity of natural killer (NK) cells and cytotoxic T lymphocytes (CTL), migration and adhesion of immune cells, cytokine and growth factor regulation and toll-like receptor signalling. Cystatins are probably involved in the regulation of all these processes; importantly, cystatin $F$ has a crucial role in the regulation of immune cell cytotoxicity. NK cells and CTLs exploit the granzymelperforin pathway for target cell killing, with perforin and granzymes as crucial effector molecules. Granzymes are synthesized as inactive pro-granzymes and need to be proteolytically activated by cathepsins $C$ and $H$. Cystatin $F$ is the main regulator of the activity of cathepsins $C$ and $H$ in cytotoxic cells and, consequently, regulates their cytotoxicity. The role of cystatins and cysteine cathepsins in the immune response is presented, with emphasis on their role in the regulation of cytotoxicity of $N K$ cells and CTLs.
\end{abstract}

\section{INTRODUCTION}

Deptidases are proteolytic enzymes that cleave peptide bonds. They 1 have been seen primarily as enzymes involved in food digestion and intracellular protein catabolism (1), although in past decades their important roles in diverse physiological and pathological processes, such as cell death and survival, wound healing, the immune response, viral, bacterial and parasite infections, cancer, osteoporosis, cardiovascular, neurodegenerative and inflammatory diseases have been established (2). Among those peptidases involved in immune processes, many studies have been focused on a group of endosomal/lysosomal cysteine peptidases, the cysteine cathepsins, whose involvement in antigen processing and presentation, cytotoxicity of natural killer (NK) cells and cytotoxic T lymphocytes (CTL), migration and adhesion of immune cells, cytokine and growth factor regulation and toll like receptor (TLR) signalling have been demonstrated $(3,4)$. In addition to cathepsins, another lysosomal cysteine peptidase, legumain or asparaginyl endopeptidase, has also been associated with the immune response, most notably with antigen presentation and TLR signalling $(4,5)$. The activities of cysteine cathepsins and legumain are regulated on different levels. Their expression, for example, is regulated at transcriptional or translational levels. They are synthesised as inactive precursors, activated only at the 
site of action, and compartmentalised into lysosomes or other organelles. Their activity can be regulated by oxidation of the active site cysteine or by endogenous protein inhibitors (6), the latter being presented in more detail.

\section{CYSTEINE CATHEPSINS AND LEGUMAIN AS REGULATORS OF THE IMMUNE RESPONSE}

In humans, cysteine cathepsins comprise a group of 11 lysosomal peptidases (cathepsins B, C, F, H, K, L, O, S, $\mathrm{V}, \mathrm{X}$ and $\mathrm{W}$ ). They are members of the papain family, classified as clan CA (7). The expression pattern, levels, localization and specificities of cysteine cathepsins differ, contributing to their various physiological roles. Cathepsins $\mathrm{B}, \mathrm{H}, \mathrm{L}$ and $\mathrm{C}$ are expressed ubiquitously in cells and tissues, while expression of others is restricted to specific cell types. They are endopeptidases, with the exception of cathepsins B, C, H and X. Cathepsins B and X are carboxypeptidases, cleaving substrates at the $\mathrm{C}$-terminal end, while cathepsins $\mathrm{B}$ and $\mathrm{H}$ are aminopeptidases, cleaving substrates at the $\mathrm{N}$-terminal end. Interestingly, in addition to exopeptidase activity, cathepsins $\mathrm{B}$ and $\mathrm{H}$ also exhibit endopeptidase activity $(7,8)$. Cathepsin B can act as an endo- or exopeptidase due to the position of the structural element, termed the occluding loop, while in cathep$\sin \mathrm{H}$ the type of activity is determined by a minichain, an octapeptide derived from the pro-peptide that is bound to the mature enzyme by a disulphide bond. In the absence of a minichain, cathepsin $\mathrm{H}$ acts mainly as an endopeptidase (1). Cysteine cathepsins are predominantly localized within the endosomal/lysosomal pathway, however, they have been found also in the nucleus, the cytosol, on the cell membrane or secreted from the cells (9). They participate in numerous physiological processes, not only in terminal protein degradation in the endosomal/lysosomal pathway, but also in proteolytic activation of prohormones. For example, in the thyroid, liberation of the thyroid hormone thyroxin from its pro-hormone thyroglobulin is mediated by cysteine cathepsins (10). In addition, cysteine cathepsins activate other protein precursors and are thus important in several other cell processes including antigen presentation and processing (6). Secreted cysteine cathepsins on the other hand are important in the remodelling of the extracellular matrix and, consequently, in wound healing, bone remodelling and tumour cell invasion $(6,11)$. Furthermore, the activity of extralysosomal cathepsins can regulate apoptosis, a process crucial in homeostasis of immune and other cells (12). For instance, cathepsins B, H, K, L and S process the pro-apoptotic molecule Bid, while cathepsins B, H, L, K and $S$ degrade anti-apoptotic molecules $\mathrm{Bcl}-2$, Bcl-xL and Mcl-1, thereby triggering apoptosis (12-14).

Legumain is a member of C13 family of cysteine peptidases. It has a broad tissue distribution, being most abundant in kidney and testis and in various types of antigen presenting cells. Inside the cells it is present in the endosomal/lysosomal pathway, where it acts as an endopeptidase. However, legumain is also found in the cytosol, nucleus or extracellularly and, in addition to its endopeptidase activity, also acts as a carboxypeptidase and peptide ligase (5).

Cysteine cathepsins are involved in various aspects of innate and adaptive immune response. In the innate response they were shown to regulate TLR signalling. The first cathepsin shown to be implicated in this process was cathepsin K. Its pharmacological or genetic inhibition leads to reduction in TLR9-induced signalling (15). Cathepsins $\mathrm{B}, \mathrm{L}, \mathrm{S}$ and $\mathrm{F}$ can also regulate TLR9 function (16-18). Cathepsins cleave the ectodomain of TLR9 and, although the full-length and cleaved forms can both bind their ligands, only the cleaved form can recruit the signalling adaptor MyD88 on activation $(16,17)$. The cleavage is a stepwise process where most of the ectodomain is first removed by legumain and cathepsins, followed by trimming of the exposed N-terminal catalysed only by cathepsins (19). Nevertheless, in the absence of legumain cathepsins seem to be sufficient to carry out TLR processing. TLR 3 and 7 are processed in the same manner (19), suggesting that proteolytic activation of TLR receptors may be a general regulatory strategy, important in preventing unwanted responses to self-nucleic acids (19).

Cathepsins are also involved in cytokine activation and/or inhibition. For example, interleukin-8 (IL-8) is activated by $\mathrm{N}$-terminal truncation by cathepsin $\mathrm{L}$ in human fibroblasts (20) and optimal trafficking and processing of tumour necrosis factor $\alpha$ (TNF- $\alpha$ ) is dependent on cathepsin B activity (21). On the other hand, cytokines can regulate the activity of cathepsins like TNF- $\alpha$ and IL-1 $\beta$ that increase the activity of cathepsins $S$ and B in dendritic cells, enhancing major histocompatibility complex (MHC) class II dimer formation and T cell recognition (22).

Cathepsin X has been shown to modulate signal transduction by interacting with integrin receptors. It can interact independently of proteolysis, through direct binding of the RGD motif in pro-cathepsin $\mathrm{X}$ with integrins or via proteolysis, through cleavage of integrin receptors by active cathepsin $X(23,24)$. In macrophages and monocytes, cleavage of $\beta 2$-integrin receptor Mac-1 (CD11b/CD18) leads to increased phagocytosis, cell adhesion and activation of $\mathrm{T}$ lymphocytes (25) while, in dendritic cells, this cleavage is required for their adhesion and maturation (26).

Cysteine peptidases are probably best known for their role in the activation and migration of T lymphocytes. In the latter, for example, cathepsin X modulates the activity of $\beta 2$ integrin receptor lymphocyte function-associated antigen 1 (LFA-1), thus enhancing $\mathrm{T}$ lymphocyte migration and homotypic aggregation (27). Even more prominent is the involvement of cysteine cathepsins in activation of MHC class II-dependent T cells. In antigen presenting cells they participate in two main processes, 
the first being the degradation of invariant chain (Ii), a chaperone that prevents premature loading of peptide to MHC class II molecules, while the second one is the degradation of endocytosed antigens to antigenic peptides. The degradation of Ii is a stepwise process including, first, formation of the $22 \mathrm{kDa}$ LIP (leupeptin-induced protein)fragment, followed by formation of the $10 \mathrm{kDa}$ SLIP (small-leupeptin-induced protein)-fragment and finally CLIP (class-II associated invariant chain peptide)-fragment (28). The rate-limiting step is the conversion of SLIP to CLIP, catalysed by cathepsin S in dendritic and B cells, by cathepsin V in thymic epithelial cells and by both enzymes in macrophages (29). In macrophages an additional peptidase, cathepsin F, can also catalyse the final Ii degradation step (30). The first steps of Ii processing in antigen presenting cells are less specific and involve multiple peptidases, among them legumain. However, it is not clear whether legumain cleaves Ii directly or is involved in Ii processing indirectly, through activation of cathepsins (31-33). In addition to preventing premature peptide loading, Ii is also involved in the migration of dendritic cells. Accumulation of Ii inhibits dendritic cell migration while proteolytic degradation of Ii makes them migrate faster (34). The degradation of endocytosed proteins into immunogenic peptides involves various cathepsins, as well as legumain. The difference in generation as well as distruction of immunogenic peptides may trigger specific MHC class II dependent T cell response (28).

Last, but not least, cathepsins are also important for the activation of granule-localized serine peptidases from their precursor forms, including cathepsin G, elastase and proteinase-3 in neutrophils, granzymes A and B in NK and $\mathrm{T}$ cells and chymase in mast cells (4). These serine peptidases are the main executors of the effector functions of these cells. However, there is considerable redundancy in the mechanism of activation of granule-localized serine peptidases in cytotoxic cells. The first peptidase discovered was cathepsin $\mathrm{C}$, which removes two residues from the N-terminus (35). Accordingly, cathepsin C null mice were not able to activate neutrophil and mast cell granule peptidases $(36,37)$ however, in cytotoxic $\mathrm{T}$ cells, granzyme $\mathrm{B}$ activity was reduced, but not absent (38). Likewise, in Papillon-Lefévre syndrome, a genetic disorder characterised by cathepsin $\mathrm{C}$ deficiency, severe gingivitis and skin infections are present, but not a general T-cell immunodeficiency (39). These results suggested that there are other peptidases involved in granzyme activation and, for granzyme B, cathepsin $\mathrm{H}$ was found as an additional peptidase. However, cytotoxic lymphocytes from cathepsin $\mathrm{C}$ and $\mathrm{H}$ null mice still retain residual granzyme $\mathrm{B}$ activity, implying that further peptidases are involved in granzyme $\mathrm{B}$ activation (40). In addition to activation of granule-localized serine peptidases, cathepsins are also involved in perforin processing in cytotoxic cells. Perforin, the pore-forming protein of cytotoxic granules, is cleaved by cathepsin L at the C-terminus. Again, other cathepsins are probably also involved in perforin activation (41).

\section{CYSTATINS AND THE IMMUNE RESPONSE}

Cystatins constitute a superfamily of evolutionarily related proteins, with representatives present in all living organisms, from protozoa to mammals. They act as inhibitors of cysteine peptidases from $\mathrm{C} 1$ family, but some members can inhibit the C13 family by a second active site (42). Based on their structure, human cystatins can be divided into three types. Type I cystatins, stefins A and $\mathrm{B}$, are approximately 100 amino acid residues long, they are not glycosylated and do not contain disulphide bonds. They are found mainly intracellularly but can also be secreted. Type II cystatins, cystatins C, D, E/M, F, S, SA, SN, CRES, testatin, cystatins 11, 12, 13 and 14, have approximately 120 amino acid residues, contain two conserved disulphide bridges and are mainly secreted to the extracellular space. The most complex are type III cystatins, the kininogens, that contain three type II domains. They contain approximately 350 amino acid residues, have eight disulphide bonds and are glycosylated. They are secreted extracellularly and found intravascularly, where they provide systemic protection against leaking endolysosomal cysteine peptidases $(43,44)$.

Cystatins function mainly as reversible, tight-binding inhibitors of cysteine cathepsins, and are involved in several immune processes controlling the cathepsins. In addition to inhibiting endogenous cysteine peptidases, they can also inhibit cysteine peptidases from microorganisms and parasites, helping in defence against microbial infections (44). Furthermore, cystatins can also act independently from their inhibitory function; for example cystatin $\mathrm{C}$ was shown to interact with transforming growth factor $\beta$ (TGF- $\beta$ ) type II receptor, thus interfering with TGF- $\beta$ binding (45).

Stefin A has a broad inhibitory profile, but shows selective expression in tissues involved in the first-line immune response like skin epithelial cells (46) and polymorphonuclear granulocytes (47); it might be thus relevant for inhibiting peptidases from microbes invading through the skin. Furthermore, stefin A was proposed to have an important function in the development of the epidermis and in the associated neonatal immune response (48). It is also highly expressed in follicular dendritic cells of germinal centres in secondary lymphoid organs, that select $\mathrm{B}$ cells during germinal centre reactions (49). In this process stefin A is transported from follicular dendritic cells to B cells, where it could prevent apoptosis (50).

Stefin B, on the other hand, is present in most human cells (51). In the immune response its expression was shown to be upregulated in human monocytes after lipopolysaccharide (LPS) stimulation, implying its involvement in the response to bacterial infections (52). In addition, in mouse peritoneal macrophages activated with interferon $\gamma$ (IFN- $\gamma$ ), addition of stefin B enhanced nitric oxide production through a mechanism distinct from its 
inhibitory activity (53). It was further demonstrated that stefin B deficiency in bone marrow-derived macrophages leads to decreased expression of IL-10 and increased secretion of nitric oxide, consistent with a pro-inflammatory phenotype (54). Similarly, stefin B null mice, characterised by a phenotype similar to Unverricht-Lundborg disease, were significantly more sensitive to LPS-induced sepsis and contained larger amounts of pro-inflammatory cytokines IL- $1 \beta$ and IL-18 in the serum (55). In a recent study it was confirmed that stefin B deficiency in stefin B null mice leads to down-regulation of IFN regulated genes in microglia, the resident tissue macrophages in the central nervous system, providing a general mechanism for stefin B involvement in innate immune response (56).

Cystatin D is found in saliva and tears in humans (57), where it probably functions as an inhibitor of exogenous peptidases. Indeed, it has been found to be a potent inhibitor of coronavirus replication (58). In a recent study it was shown that, in rats, cystatin $\mathrm{D}$ is produced and secreted by parotid acinar cells, but also in antigen presenting cells in parotid glands, even if the cystatin $\mathrm{D}$ gene was not expressed in these cells (59). This suggests that cystatin D, similarly to cystatin F as described below, can act in trans. Cystatin D localization in antigen presenting cells and its preferential inhibition of cathepsin S (60) suggest, that it could be involved in antigen presentation.

Cystatins S, SN and SA are non-glycosylated proteins found in saliva, tears, urine, seminal plasma, liver and muscle (61). Because of their glandular localization they probably also act as inhibitors of exogenous peptidases. Accordingly, they were found to be effective inhibitors against cysteine peptidases from parasites, for example cruzipain from Trypanosoma cruzi (62). Furthermore, they might play a role in protection against viral infections, as they can suppress the infectivity of herpes simplex virus 1 (63) and were found up-regulated in children with seasonal influenza A infection (64). Similarly, cystatin $\mathrm{SN}$ was up-regulated in patients with seasonal allergic rhinitis (65) and may play a role in the inactivation of peptidase allergens. In addition to their role in inhibiting exogenous peptidases, incubation of human CD4+ T cells with cystatin SA leads to increased IFN- $\gamma$ production (66) additionally confirming a role for salivary cystatins in the immune response.

Of the type II cystatins the most important role in the immune response is attributed to cystatins $\mathrm{C}$ and $\mathrm{F}$. Cystatin $\mathrm{C}$ is the most abundant human cystatin, expressed in all human tissues and cell types. Like most type II cystatins it is secreted and found at high levels in body fluids, where it most probably acts as an emergency inhibitor, neutralizing redundant proteolytic activity outside cells $(44,51)$. It has diagnostic and prognostic value in several diseases; for example it is a marker of glomerular filtration rate and thus of kidney function (51). Levels of serum cystatin $\mathrm{C}$ are associated with inflammation in systemic lupus erythematosus (67) In addition, it has been found to be a positive acute-phase reactant in chronic obstructive pulmonary disease (68). Furthermore, cystatin C expression and protein levels were found to be decreased following maturation of dendritic cells $(69,70)$. It has been suggested that cystatin $\mathrm{C}$ plays a role in antigen presentation by regulation of cathepsin $S$ activity, however, studies on dendritic cells from cystatin $\mathrm{C}$ null mice showed that cystatin $\mathrm{C}$ is not involved in this process (71).

Cystatin $\mathrm{F}$ is expressed primarily in cells of the immune system, such as dendritic cells, T cells and NK cells (72-74). While other type II cystatins are mainly secreted, the intracellular levels of cystatin $\mathrm{F}$ are unusually high, implying an important intracellular role (75). It is expressed as a disulphide linked dimer and targeted to the endosomal/lysosomal pathway through the mannose-6phosphate sorting machinery (76), where it can regulate the activity of cysteine peptidases. However, cystatin F is not active as an inhibitor of cysteine cathepsins until it is converted to the monomeric form (77). Dimer to monomer conversion is facilitated by proteolytic cleavage at the $\mathrm{N}$-terminus (78), probably by cathepsin V (41). Proteolytic processing changes its inhibitory profile and, while full-length cystatin $\mathrm{F}$ inhibits legumain and cathepsins $\mathrm{F}$, $\mathrm{H}, \mathrm{K}, \mathrm{L}, \mathrm{S}$ and $\mathrm{V}(77)$, the $\mathrm{N}$-terminal processing is essential for cathepsin $\mathrm{C}$ inhibition (78). In addition, intracellular localization of the dimeric and monomeric forms is different: the dimeric form is found primarily in endoplasmic reticulum and Golgi apparatus, while the monomeric form is found in lysosomes and is completely truncated at the $\mathrm{N}$-terminus (78). Furthermore, the secreted dimeric cystatin $\mathrm{F}$ can be internalized by other cells through the mannose-6-phosphate receptor pathway and can thus function also in trans (76). Levels and localization of cystatin $\mathrm{F}$ depend on the physiological state of the cell. For example, cystatin F is strongly upregulated in LPS-stimulated monocyte derived dendritic cells (69) and downregulated by all-trans-retinoic acid in the U937 cell line differentiated towards the granulocytic pathway or by, phorbol ester, towards macrophages (75). Furthermore, cystatin $\mathrm{F}$ co-localizes with cathepsin $\mathrm{S}$ in immature dendritic cells, suggesting that it could reduce cathep$\sin S$ activity in the earlier steps of dendritic cell maturation (79). In the same study cystatin F was found co-localized with cathepsin L in maturing, adherent dendritic cells. Through regulation of cathepsin L activity, cystatin F could regulate pro-cathepsin X activity, which is involved in adhesion and maturation of dendritic cells as described above. Moreover, cystatin F has been shown to be an important survival factor for eosinophils (80). Eosinophils from cystatin F null mice had lower granularity and faster turnover than those from wild-type mice. In a model of ovalbumin-specific allergic lung inflammation, the accumulation of eosinophils in the airways of cystatin F null mice was significantly lower than that in those of the wildtype, while the incidence of early apoptotic eosinophils was higher, suggesting a role for cystatin $\mathrm{F}$ in eosinophil survival. Furthermore, cystatin F null mice infected with 
nematode parasite Burgia malayi were unable to eliminate the infection, while wild-type mice successfully cleared the parasite. Abnormal granule biogenesis and the shorter lifespan of cystatin F null eosinophils is most probably a consequence of dysregulated activity of cysteine cathepsins that leads to disturbed processing of multiple granule constituents, such as major-basic protein-1. However, no one peptidase was found to be the target of cystatin $\mathrm{F}$ in eosinophils, and it is likely that cystatin F functions through regulation of multiple peptidases. (80). Cystatin $\mathrm{F}$ is also an important regulator of $\mathrm{NK}$ and $\mathrm{T}$ cell cytotoxicity - it regulates the activity of granzyme convertases cathepsins $\mathrm{C}$ and $\mathrm{H}$. This will be explained in more detail in the following sections.

\section{CYTOTOXIC IMMUNE CELLS}

Cytotoxic immune cells include CTLs and NK cells and constitute the major effector mechanism in the cellular immune response against microbial infections and cancer cells (81). Even though the activation of CTLs differs from that of NK cells, the molecular mechanisms they employ for target cell killing are basically the same and include at least three distinct pathways. Two of these, i.e. the death receptor and granzyme/perforin pathways, employ direct cell-cell contact, while the third mechanism is mediated by secreted cytokines, e.g. IFN- $\gamma$ and TNF- $\alpha$. The death receptor pathway involves binding of Fas, a ligand expressed on the surface of cytotoxic cells, to the Fas receptor on the target cell, after which apoptosis is triggered in a caspase-dependent manner. The granzyme/ perforin pathway involves exocytosis of cytotoxic granules containing perforin and granzymes into the intracellular space and subsequent diffusion of granzymes into the target cell. Once in the target cell, granzymes trigger caspasedependent or independent cell death (81-83). The death receptor pathway is exploited primarily for elimination of self-reactive lymphocytes (84), while the granzyme/perforin pathway is used by cytotoxic cells for elimination of virus-infected and transformed cells (81).

Perforin and granzymes are located in cytotoxic granules, also termed 'secretory lysosomes' (85). In addition to perforin and granzymes, the cytotoxic granules contain several other molecules, such as cysteine peptidases cathepsins $\mathrm{C}, \mathrm{H}$ and $\mathrm{L}$ and lysosomal membrane proteins Lamp-1, Lamp-2 and Lamp-3 (40, 86).

Perforin is a cytotoxic, pore-forming protein, a typical member of membrane attack complex/perforin (MACPF) protein family. It consists of an N-terminal MACPF/cholesterol dependent cytolysin domain with amphipathic helices for membrane protrusion, an epidermal growth factor domain with unknown function, and a C-terminal C2 domain responsible for calcium-dependent membrane binding (87). Perforin is synthesised as an inactive precursor requiring proteolytic cleavage at the $\mathrm{C}$-terminal for its activation (88). However, it was shown that perforin with intact C-terminal has unchanged activity, making the role of proteolytic cleavage unclear (89). Perforin is essential for diffusion of granzymes into the target cell; perforin null mice completely lose their ability to kill target cells through the perforin/granzyme pathway and become susceptible to various immunogenic challenges, such as viral infection (90). In humans, defects in perforin synthesis, function or release lead to familial haemophagocytic lymphohistiocytosis, a severe immunoregulatory disorder (90).

Granzymes are a family of structurally related neutral serine peptidases. In humans five different granzymes have been described, granzymes A, B, H, M and K, with different substrate specificities and expression (91, 92). Similarly to other serine peptidases, granzymes are activated by a two-step process. They are first targeted to the endoplasmic reticulum and Golgi apparatus, where the leader sequence is removed, whereas a dipeptide remains at the $\mathrm{N}$-terminal (93). Inside cytotoxic granules this dipeptide is cleaved off and the granzymes are activated. Cleavage of the dipeptide is carried out primarily by cathepsin $\mathrm{C}$ however, at least for granzyme $\mathrm{B}$, it can be catalysed also by cathepsin $\mathrm{H}(40,94)$. The expression of granzymes is in generally limited to lymphoid cells and the only cells known to synthesize and store granzymes constitutively are NK cells, natural killer T cells (NKT), and $\gamma \delta$ T cells, whereas in other cells granzymes are expressed only after stimulation, e.g. antigen stimulation in CTLs (92). In addition, non-cytotoxic roles for granzymes have been proposed, such as direct cleavage of viral proteins or activation of pro-inflammatory cytokines (83).

Even though they possess the same cytotoxic mechanism, NK cells and CTLs differ in several other aspects. NK cells are one of key components of the innate immune response and are morphologically characterized as large granular lymphocytes and, phenotypically, as CD56+ CD3- cells. In the peripheral blood they constitute the third largest population of lymphocytes after $\mathrm{T}$ and $\mathrm{B}$ cells (95). Based on the expression of CD56, NK cells can be divided into two subsets, CD56 $6^{\mathrm{dim}}$ and CD56 $6^{\text {bright }}$. CD$56^{\text {dim }} \mathrm{NK}$ cells form $90 \%$ of the NK cell population in the peripheral blood, express low affinity Fc receptor (CD16) and are considered to be the main mediators of the cytotoxic response. CD56 $6^{\text {bright }}$ on the other hand are immature-like cells and are primarily involved in production of cytokines (96). NK cell activity is independent of antigen presentation and involves several inhibitory and activation receptors. The inhibitory receptors, e.g. KIR2DL or CD158/KIR3DL, bind to MHC class I molecules, the lack of which then triggers NK cell activation. However, for full NK cell activation, additional activating signals have to be present. The activation receptors, e.g CD16 or NKG2D, bind ligands on tumour and virus-infected cells. CD16 is an Fc $\gamma$ receptor and binds to antibody coated targets, while NKG2D recognizes autologous ligands that are upregulated by transformation, infection or cell stress (97). A single cell can express from two to four 
inhibitory receptors and several activation receptors, then becoming activated only if activation signals outnumber the inhibitory signals (95). In addition, several cytokines, such as IL-2, IL-12, IL-15 and type I IFNs (IFN- $\alpha$ and IFN- $\beta$ ), can enhance the cytolytic, secretory, proliferative and anti-tumour NK cell functions $(98,99)$.

Apart from NK cells, other types of innate immune cell, monocytes and macrophages, can also destroy antibody coated targets via antibody-dependent cell cytotoxicity; but the underlying mechanisms were unclear. However, it was recently shown that activation of $\mathrm{Fc} \gamma$ receptor on monocytes triggers production of granzyme $B$ and that granzyme B is responsible for a substantial portion of monocyte antibody-dependent cell cytotoxicity (100). Furthermore, activation of TLR8 also led to production of granzyme $\mathrm{B}$ and simultaneous activation of $\mathrm{F} \gamma \gamma$ receptor and TLR8 resulted in an additive effect. Moreover, treatment with TLR8 agonist also induced perforin and serpin B9 expression. These two reactions explain how monocytes can deliver granzyme B into the target cells and how they protect themselves, respectively (100).

CTLs on the other hand are the major component of the adaptive immune response. They develop from naive CD8+ T cells in the process of effector $T$ cell differentiation. Naive CD8+ T cells are small round cells that do not contain cytotoxic granules and circulate the periphery. When they encounter the antigen presented by MHC class I molecules and in the presence of the appropriate co-stimulation on the surface of professional antigen presenting cells, the T-cell receptor engagement triggers a cascade of intracellular events, ultimately leading to $T$ cell activation. T cell activation leads to rapid clonal expansion and effector differentiation and, in a few days, naive CD8+ cells differentiate into effector CTLs. CTLs are loaded with granzymes and perforin, in cytotoxic granules. Recognition of target cells by CTLs in the periphery leads to rapid polarized secretion of cytotoxic granules at the site of cell contact and triggers target cell apoptosis (3, 101, 102).

\section{REGULATION OF CELL CYTOTOXICITY BY CYSTATINS}

Cystatins and cathepsins are involved in several processes that regulate the cytotoxicity of NK cells and CTLs. In this regard their most important function is regulation of granzyme activation. (93). As noted above, the main cathepsin responsible for granzyme activation is cathepsin $\mathrm{C}$ but, at least for granzyme $\mathrm{B}$, the alternative pro-granzyme convertase is cathepsin $\mathrm{H}$. Furthermore, even cathepsin $\mathrm{C}$ and $\mathrm{H}$ null mice exhibit some residual granzyme $\mathrm{B}$ activity, suggesting another mechanism of activation (40).

The role of cystatins in regulation of cell cytotoxicity is less known. Cystatin C has been suggested as regulating

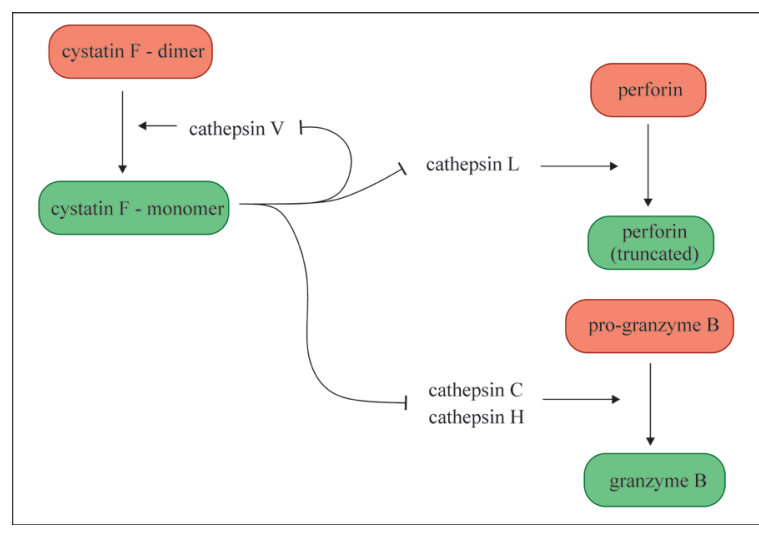

Figure 1. Schematic representation of the role of cystatin $F$ and cysteine cathepsins in activation of effector molecules in cytotoxic cells. Cystatin F dimer is inactive as inhibitor of cysteine cathepsins. For monomerisation and activation it first needs to be proteolitically processed at the $N$-terminus, presumably by cathepsin $V$. Truncated monomeric cystatin $F$ becomes an inhibitor of cathepsins $L$, $C$ and $H$ and thus inhibits perforin processing and granzyme activation.

cathepsin $S$ activity and invariant chain (Ii) processing in dendritic cells (DCs), however, further studies excluded its role in controlling MHC II-dependent antigen presentation in DCs. Cystatin SN has been found also in dendritic cells exposed to Toxoplasma gondii and it could thus modulate antigen presentation and consequently cell cytotoxicity of T cells (51). However, in cytotoxic cells the most prominent role in the regulation of cathepsin activity is attributed to cystatin F (Figure 1). Its preferential expression in immune cells and its endosomal/lysosomal localization already imply an important role in the immune response $(73,76)$. In addition, cystatin $\mathrm{F}$ was found co-localized with granzyme A, perforin and Lamp-1 in human CD8+ T blasts, its overexpression in mouse CTLs led to decreased activity of cathepsin C (78). Another interesting feature of cystatin $\mathrm{F}$ is its ability to function in trans. It was shown that cystatin F null CTLs can take up cystatin F secreted by other CTLs. Furthermore, the internalized cystatin $\mathrm{F}$ was shown to attenuate cathepsin $\mathrm{C}$ activity directly (76). Localization of cystatin $\mathrm{F}$ in cytotoxic granules and its ability to regulate cathepsin $\mathrm{C}$ activity are strong advocates for its important role in the regulation of cytotoxicity of CTLs.

Expression of cystatin $\mathrm{F}$ is even higher in NK cells than in CTLs (74). In NK92 cell line cystatin F was found localized in lysosomes, co-localized with cathepsins $\mathrm{C}$ and $\mathrm{H}$ (104) (Figure 2). Like cystatin F in CTLs, in NK92 cells as well as in primary human NK cells the monomeric form of cystatin $\mathrm{F}$ is $\mathrm{N}$-terminally truncated (104), implying its inhibitory potential for cathepsin $\mathrm{C}$ and the regulation of cell cytotoxicity. In fact, it was shown by our group that higher levels of cystatin F in NK cells are associated with lower cytotoxicity and, concurrently, with the ability of NK cells to proliferate and secrete cytokines 
Figure 2. Proximity ligation assay showing co-localization/interaction of cystatin $F$ with cathepsin C [1] and cathepsin $H$ [2] in NK92 cell line. DAPI stained nuclei $(A)$, proximity ligation assay signals $(B)$, merged $(C)$. White bar represents $10 \mu \mathrm{m}$. The method was performed as described (103). The images were taken on Carl Zeiss LSM 710 confocal microscope. Each green dot represents co-localisation of cystatin F with cathepsin C [1] or cathepsin $H[2]$.
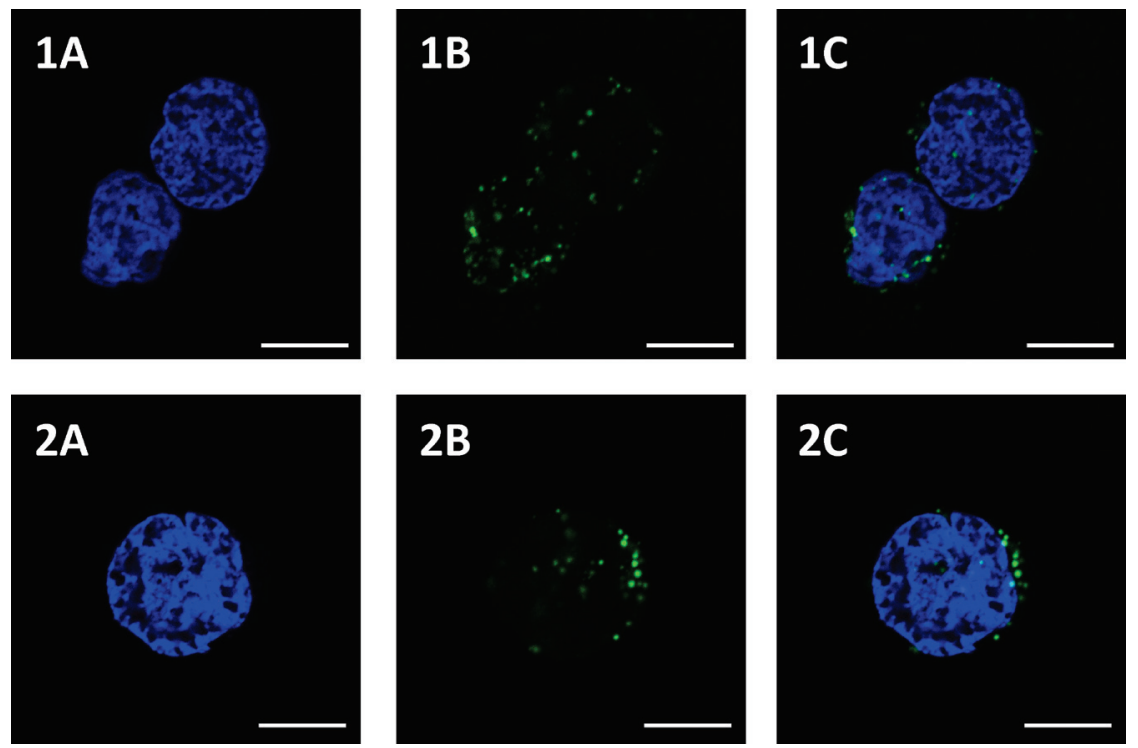

(104). This cell status was termed split anergy by Jewett and colleagues to describe loss of NK cell cytotoxicity after their interaction with sensitive target cells (105). Interaction of NK cells with NK sensitive targets, such as tumour cells or monocytes, in some cases causes loss of cytotoxicity and triggers secretion of TNF- $\alpha$ and IFN- $\gamma$, whereas their interaction with NK resistant targets does not (106). Split anergy involves down-modulation of CD16 receptor expression and can be induced by triggering CD16 with, for example, anti-CD16 antibodies in the presence or absence of IL-2. It was proposed that anergized NK cells are important for tissue differentiation, regeneration and resolution of inflammation, while nonanergized NK cells are important for stem cell selection (105). In anergized NK cells, levels of cathepsin C heavy chain were found to be lower than in IL-2 treated and non-treated NK cells, indicating decreased processing of pro-cathepsin $\mathrm{C}$ to mature cathepsin $\mathrm{C}$ after CD16 triggering. Similarly, cathepsin $\mathrm{H}$ and granzyme B levels were also lower following CD16 triggering in the presence of IL-2 (104). On the other hand, the level of the cystatin F truncated monomeric form was significantly increased (104), potentiating inactivation of the convertase function of cathepsins $\mathrm{C}$ and $\mathrm{H}$.

Increased levels of cystatin F could, in addition, contribute to inhibition of other cathepsins such as cathepsin $\mathrm{L}$ and legumain. Interestingly, NK cells from legumain null mice display lower cytotoxicity, implying an important role for legumain as well in cytotoxic cells (107). However, the mechanism underlying legumain involvement in cytotoxicity is not known, though one possibility is through processing of either cathepsin $\mathrm{L}$ or $\mathrm{H}$ from their single chain to two chain forms (33). The fact that internalized exogenous cystatin F stabilizes cathepsin L protein levels and inhibits legumain in bone marrow-derived dendritic cells and macrophages supports this thesis (108).

\section{CONCLUSIONS}

Cysteine cathepsins and legumain are peptidases involved in a variety of immune processes, among them activation of granule serine peptidases, a prerequisite step in the activation of cell cytotoxicity. Their function is regulated by the endogenous protein inhibitors cystatins. The most important of them is cystatin $\mathrm{F}$ that inhibits cathepsins $\mathrm{C}$ and $\mathrm{H}$ and consequently regulates the activation of granzymes. It can also regulate cytotoxic cell function through inhibition of cathepsin $\mathrm{L}$ and legumain and, in NK cells, cystatin F can promote split anergy, a type of NK cell response characterized by loss of cytotoxicity associated with failure of the anti-tumour immune response.

Acknowledgement: Authors thank prof. Roger Pain for critical reading of the manuscript. The research work was supported by Slovenian Research Agency, grants P4-0127 and J4-6811 (J.K.).

\section{REFERENCES}

1. BARRETT AJ, RAWLINGS ND, WOESSNER JF 2012 Handbook of Proteolytic Enzymes. Academic Press, London

2. TURK B, TURK D, TURK V 2012 Protease signalling: the cutting edge. EMBO J 31(7):1630-43.

https://doi.org/10.1038/emboj.2012.42

3. PERIŠIĆ NANUT M, SABOTIČ J, JEWETT A, KOS J 2014 Cysteine cathepsins as regulators of the cytotoxicity of $\mathrm{NK}$ and $\mathrm{T}$ cells. Front Immunol 5:616.

https://doi.org/10.3389/fimmu.2014.00616

4. COLBERT JD, MATTHEWS SP, MILLER G, WATTS C 2009 Diverse regulatory roles for lysosomal proteases in the immune response. Eur J Immunol 39(11):2955-65. https://doi.org/10.1002/eji.200939650

5. DALL E, BRANDSTETTER H 2016 Structure and function of legumain in health and disease. Biochimie 122:126-50.

https://doi.org/10.1016/j.biochi.2015.09.022 
6. TURK V, STOKA V, VASILJEVA O, RENKO M, SUN T, et al. 2012 Cysteine cathepsins: from structure, function and regulation to new frontiers. Biochim Biophys Acta 1824(1):68-88

7. RAWLINGS ND, WALLER M, BARRETT AJ, BATEMAN A 2014 Merops: the database of proteolytic enzymes, their substrates and inhibitors. Nucleic Acids Res 42(Database issue):D503-9. https://doi.org/10.1093/nar/gkt953

8. TURK V, TURK B, TURK D 2001 Lysosomal cysteine proteases: facts and opportunities. EMBO J 20(17):4629-33. https://doi.org/10.1093/emboj/20.17.4629

9. OBERMAJER N, DOLJAK B, KOS J 2006 Cysteine cathepsins: regulators of antitumour immune response. Expert Opin Biol Ther 6(12):1295-1309. https://doi.org/10.1517/14712598.6.12.1295

10. BRIX K, LINKE M, TEPEL C, HERZOG V 2001 Cysteine proteinases mediate extracellular prohormone processing in the thyroid. Biol Chem 382(5):717-25. https://doi.org/10.1515/bc.2001.087

11. BRIX K, DUNKHORST A, MAYER K, JORDANS S 2008 Cysteine cathepsins: cellular roadmap to different functions. Biochimie 90(2):194-207. https://doi.org/10.1016/j.biochi.2007.07.024

12. PIŠLAR A, PERIŠIĆ NANUT M, KOS J 2015 Lysosomal cysteine peptidases - molecules signaling tumor cell death and survival Semin Cancer Biol. 35:168-79. https://doi.org/10.1016/j.semcancer.2015.08.001

13. STOKA V, TURK B, SCHENDEL SL, KIM TH, CIRMAN T, et al. 2001 Lysosomal protease pathways to apoptosis. Cleavage of bid, not pro-caspases, is the most likely route. J Biol Chem 276(5):314957. https://doi.org/10.1074/jbc.M008944200

14. DROGA-MAZOVEC G, BOJIČ L, PETELIN A, IVANOVA S, ROMIH R, et al. 2008 Cysteine cathepsins trigger caspase-dependent cell death through cleavage of bid and antiapoptotic bcl-2 homologues. J Biol Chem 283(27):19140-50. https://doi.org/10.1074/jbc.M802513200

15. ASAGIRI M, HIRAI T, KUNIGAMI T, KAMANO S, GOBER $\mathrm{H}-\mathrm{J}$, et al. 2008 Cathepsin K-dependent toll-like receptor 9 signaling revealed in experimental arthritis. Science 319(5863):624-27. https://doi.org/10.1126/science.1150110

16. PARK B, BRINKMANN MM, SPOONER E, LEE CC, KIM Y-M, PLOEGH HL 2008 Proteolytic cleavage in an endolysosomal compartment is required for activation of toll-like receptor 9. Nat Immunol 9(12):1407-14. https://doi.org/10.1038/ni.1669

17. EWALD SE, LEE BL, LAU L, WICKLIFFE KE, SHI G-P, et al. 2008 The ectodomain of toll-like receptor 9 is cleaved to generate a functional receptor. Nature 456(7222):658-62.

https://doi.org/10.1038/nature07405

18. MATSUMOTO F, SAITOH S, FUKUI R, KOBAYASHI T, TANIMURA N, et al. 2008 Cathepsins are required for toll-like receptor 9 responses. Biochem Biophys Res Commun 367(3):693-99. https://doi.org/10.1016/j.bbrc.2007.12.130

19. EWALD SE, ENGEL A, LEE J, WANG M, BOGYO M, BARTON GM 2011 Nucleic acid recognition by toll-like receptors is coupled to stepwise processing by cathepsins and asparagine endopeptidase. J Exp Med 208(4):643-51. https://doi.org/10.1084/jem.20100682

20. OHASHI K, NARUTO M, NAKAKI T, SANO E 2003 Identification of interleukin-8 converting enzyme as cathepsin L. Biochim Biophys Acta 1649(1):30-39

21. HA S-D, MARTINS A, KHAZAIE K, HAN J, CHAN BMC, KIM SO 2008 Cathepsin B is involved in the trafficking of TNFalpha-containing vesicles to the plasma membrane in macrophages. J Immunol 181(1):690-97. https://doi.org/10.4049/jimmunol.181.1.690

22. FIEBIGER E, MERANER P, WEBER E, FANG IF, STINGL G, et al. 2001 Cytokines regulate proteolysis in major histocompatibility complex class II-dependent antigen presentation by dendritic cells. J Exp Med 193(8):881-92. https://doi.org/10.1084/jem.193.8.881

23. KOS J, VIŽIN T, FONOVIĆ UP, PIŠLAR A 2015 Intracellular signaling by cathepsin X: Molecular mechanisms and diagnostic and therapeutic opportunities in cancer. Semin Cancer Biol 31:76-83. https://doi.org/10.1016/j.semcancer.2014.05.001

24. LECHNER AM, ASSFALG-MACHLEIDT I, ZAHLER S, STOECKELHUBER M, MACHLEIDT W, et al. 2006 RGDdependent binding of procathepsin $\mathrm{X}$ to integrin $\alpha \mathrm{v} \beta 3$ mediates cell-adhesive properties. J Biol Chem 281(51):39588-97. https://doi.org/10.1074/jbc.M513439200

25. OBERMAJER N, PREMZL A, ZAVASNIK BERGANT T, TURK B, KOS J 2006 Carboxypeptidase cathepsin X mediates beta2-integrin-dependent adhesion of differentiated U-937 cells. Exp Cell Res 312(13):2515-27. https://doi.org/10.1016/j.yexcr.2006.04.019

26. OBERMAJER N, SVAJGER U, BOGYO M, JERAS M, KOS J 2008 Maturation of dendritic cells depends on proteolytic cleavage by cathepsin X. J Leukoc Biol 84(5):1306-15. https://doi.org/10.1189/jlb.0508285

27. JEVNIKAR Z, OBERMAJER N, BOGYO M, KOS J 2008 The role of cathepsin $\mathrm{X}$ in the migration and invasiveness of $\mathrm{T}$ lymphocytes. J Cell Sci 121(Pt 16):2652-61. https://doi.org/10.1242/jcs.023721

28. BLUM JS, WEARSCH PA, CRESSWELL P 2013 Pathways of antigen processing. Annu Rev Immunol 31:443-73. https://doi.org/10.1146/annurev-immunol-032712-095910

29. VAN KASTEREN SI, OVERKLEEFT HS 2014 Endo-lysosomal proteases in antigen presentation. Curr Opin Chem Biol 23:8-15. https://doi.org/10.1016/j.cbpa.2014.08.011

30. SHI GP, BRYANT RA, RIESE R, VERHELST S, DRIESSEN C, et al. 2000 Role for cathepsin $\mathrm{F}$ in invariant chain processing and major histocompatibility complex class II peptide loading by macrophages. J Exp Med 191(7):1177-86. https://doi.org/10.1084/jem.191.7.1177

31. MANOURY B, MAZZEO D, LI DN, BILLSON J, LOAK K, et al. 2003 Asparagine endopeptidase can initiate the removal of the MHC class II invariant chain chaperone. Immunity 18(4):489-98. https://doi.org/10.1016/S1074-7613(03)00085-2

32. MAEHR R, HANG HC, MINTERN JD, KIM Y-M, CUVILLIER A, et al. 2005 Asparagine endopeptidase is not essential for class II MHC antigen presentation but is required for processing of cathepsin L in mice. J Immunol 174(11):7066-74.

https://doi.org/10.4049/jimmunol.174.11.7066

33. SHIRAHAMA-NODA K, YAMAMOTO A, SUGIHARA K, HASHIMOTO N, ASANO M, et al. 2003 Biosynthetic processing of cathepsins and lysosomal degradation are abolished in asparaginyl endopeptidase-deficient mice. J Biol Chem 278(35):33194-99. https://doi.org/10.1074/jbc.M302742200

34. FAURE-ANDRÉ G, VARGAS P, YUSEFF M-I, HEUZÉ M, DIAZ J, et al. 2008 Regulation of dendritic cell migration by CD74, the MHC class II-associated invariant chain. Science 322(5908): 1705-10. https://doi.org/10.1126/science.1159894

35. SALVESEN G, ENGHILD JJ 1990 An unusual specificity in the activation of neutrophil serine proteinase zymogens. Biochemistry 29(22):5304-8. https://doi.org/10.1021/bi00474a013

36. WOLTERS PJ, PHAM CT, MUILENBURG DJ, LEY TJ, CAUGHEY GH 2001 Dipeptidyl peptidase I is essential for activation of mast cell chymases, but not tryptases, in mice. J Biol Chem 276(21):18551-56. https://doi.org/10.1074/jbc.M100223200

37. ADKISON AM, RAPTIS SZ, KELLEY DG, PHAM CTN 2002 Dipeptidyl peptidase I activates neutrophil-derived serine proteases and regulates the development of acute experimental arthritis. J Clin Invest 109(3):363-71. https://doi.org/10.1172/JCI0213462

38. SUTTON VR, WATERHOUSE NJ, BROWNE KA, SEDELIES $\mathrm{K}$, CICCONE A, et al. 2007 Residual active granzyme B in cathepsin C-null lymphocytes is sufficient for perforin-dependent target cell apoptosis. J Cell Biol 176(4):425-33. https://doi.org/10.1083/jcb.200609077

39. PHAM CTN, IVANOVICH JL, RAPTIS SZ, ZEHNBAUER B, LEY TJ 2004 Papillon-lefèvre syndrome: correlating the molecular, cellular, and clinical consequences of cathepsin C/dipeptidyl pepti- 
dase I deficiency in humans. J Immunol 173(12):7277-81.

https://doi.org/10.4049/jimmunol.173.12.7277

40. D'ANGELO ME, BIRD PI, PETERS C, REINHECKEL T, TRAPANI JA, SUTTON VR 2010 Cathepsin H is an additional convertase of pro-granzyme B. J Biol Chem 285(27):20514-19. https://doi.org/10.1074/jbc.M109.094573

41. MAHER K, KONJAR S, WATTS C, TURK B, KOPITAR-JERALA N 2014 Cystatin F regulates proteinase activity in IL-2-activated natural killer cells. Protein Pept Lett 21(9):957-65. https://doi.org/10.2174/0929866521666140403124146

42. ALVAREZ-FERNANDEZ M, BARRETT AJ, GERHARTZ B, DANDO PM, NI J, ABRAHAMSON M 1999 Inhibition of mammalian legumain by some cystatins is due to a novel second reactive site. J Biol Chem 274(27):19195-203. https://doi.org/10.1074/jbc.274.27.19195

43. BARRETT AJ 1986 The cystatins: a diverse superfamily of cysteine peptidase inhibitors. Biomed Biochim Acta 45(11-12):1363-74

44. ZAVASNIK-BERGANT T 2008 Cystatin protease inhibitors and immune functions. Front Biosci 13:4625-37. https://doi.org/10.2741/3028

45. SOKOL JP, SCHIEMANN WP 2004 Cystatin C antagonizes transforming growth factor beta signaling in normal and cancer cells. Mol Cancer Res 2(3):183-95

46. RÄSÄNEN O, JÄRVINEN M, RINNE A 1978 Localization of the human $\mathrm{SH}$-protease inhibitor in the epidermis. Immunofluorescent studies. Acta Histochem 63(2):193-96. https://doi.org/10.1016/S0065-1281(78)80025-7

47. BRZIN J, KOPITAR M, TURK V, MACHLEIDT W 1983 Protein inhibitors of cysteine proteinases. I. Isolation and characterization of stefin, a cytosolic protein inhibitor of cysteine proteinases from human polymorphonuclear granulocytes. Hoppe-Seylers Z Für Physiol Chem 364(11):1475-80. https://doi.org/10.1515/bchm2.1983.364.2.1475

48. SCOTT DK, LORD R, MULLER HK, MALLEY RC, WOODS GM 2007 Proteomics identifies enhanced expression of stefin A in neonatal murine skin compared with adults: functional implications. Br J Dermatol 156(6):1156-62.

https://doi.org/10.1111/j.1365-2133.2007.07875.x

49. RINNE A, DORN A, JÄRVINEN M, ALAVAIKKO M, JOKINEN K, HOPSU-HAVU VK 1986 Immunoelectron microscopical location of the acid cysteine proteinase inhibitor in the lymphatic tissue of the tonsils. Acta Histochem 79(2):137-45. https://doi.org/10.1016/S0065-1281(86)80072-1

50. VAN EIJK M, DE GROOT C 1999 Germinal center B cell apoptosis requires both caspase and cathepsin activity. J Immunol 163(5): 2478-82

51. MAGISTER S, KOS J 2013 Cystatins in immune system. J Cancer 4(1):45-56. https://doi.org/10.7150/jca.5044

52. SUZUKI T, HASHIMOTO S, TOYODA N, NAGAI S, YAMAZAKI N, et al. 2000 Comprehensive gene expression profile of LPS-stimulated human monocytes by sage. Blood 96(7):2584-91

53. VERDOT L, LALMANACH G, VERCRUYSSE V, HARTMANN S, LUCIUS R, et al. 1996 Cystatins up-regulate nitric oxide release from interferon-gamma-activated mouse peritoneal macrophages. J Biol Chem 271(45):28077-81. https://doi.org/10.1074/jbc.271.45.28077

54. MAHER K, ZAVRŠNIK J, JERIČ-KOKELJ B, VASILJEVA O, TURK B, KOPITAR-JERALA N 2014 Decreased IL-10 expression in stefin B-deficient macrophages is regulated by the MAP kinase and STAT-3 signaling pathways. FEBS Lett 588(5):720-26. https://doi.org/10.1016/j.febslet.2014.01.015

55. MAHER K, JERIČ KOKELJ B, BUTINAR M, MIKHAYLOV G, MANČEK-KEBER M, et al. 2014 A role for stefin B (cystatin B) in inflammation and endotoxemia. J Biol Chem 289(46):31736-50. https://doi.org/10.1074/jbc.M114.609396

56. KÖRBER I, KATAYAMA S, EINARSDOTTIR E, KRJUTŠKOV K, HAKALA P, et al. 2016 Gene-expression profiling suggests im- paired signaling via the interferon pathway in Cstb-/- microglia. PloS One 11(6):e0158195. https://doi.org/10.1371/journal.pone.0158195

57. FREIJE JP, BALBÍN M, ABRAHAMSON M, VELASCO G, DALBØGE H, et al. 1993 Human cystatin D. cDNA cloning, characterization of the Escherichia coli expressed inhibitor, and identification of the native protein in saliva. J Biol Chem 268(21):15737-44

58. COLLINS AR, GRUBB A 1998 Cystatin D, a natural salivary cysteine protease inhibitor, inhibits coronavirus replication at its physiologic concentration. Oral Microbiol Immunol 13(1):59-61. https://doi.org/10.1111/j.1399-302X.1998.tb00753.x

59. NASHIDA T, SATO R, HAGA-TSUJIMURA M, YOSHIE S, YOSHIMURA K, et al. 2013 Antigen-presenting cells in parotid glands contain cystatin D originating from acinar cells. Arch Biochem Biophys 530(1):32-39. https://doi.org/10.1016/j.abb.2012.12.009

60. ALVAREZ-FERNANDEZ M, LIANG Y-H, ABRAHAMSON M, SU X-D 2005 Crystal structure of human cystatin D, a cysteine peptidase inhibitor with restricted inhibition profile. J Biol Chem 280(18):18221-28. https://doi.org/10.1074/jbc.M411914200

61. DICKINSON DP 2002 Salivary (SD-type) cystatins: over one billion years in the making--but to what purpose? Cri Rev Oral Biol Med 13(6):485-508. https://doi.org/10.1177/154411130201300606

62. STOKA V, NYCANDER M, LENARCIC B, LABRIOLA C, CAZZULO JJ, et al. 1995 Inhibition of cruzipain, the major cysteine proteinase of the protozoan parasite, Trypanosoma cruzi, by proteinase inhibitors of the cystatin superfamily. FEBS Lett 370(1-2):1014. https://doi.org/10.1016/0014-5793(95)00798-E

63. GU M, HARASZTHY GG, COLLINS AR, BERGEY EJ 1995 Identification of salivary proteins inhibiting herpes simplex virus 1 replication. Oral Microbiol Immunol 10(1):54-59. https://doi.org/10.1111/j.1399-302X.1995.tb00118.x

64. TERAN LM, RÜGGEBERG S, SANTIAGO J, FUENTES-ARENAS F, HERNÁNDEZ JL, et al. 2012 Immune response to seasonal influenza A virus infection: a proteomic approach. Arch Med Res 43(6):464-69. https://doi.org/10.1016/j.arcmed.2012.08.008

65. IMOTO Y, TOKUNAGA T, MATSUMOTO Y, HAMADA Y, ONO M, et al. 2013 Cystatin SN upregulation in patients with seasonal allergic rhinitis. PloS One 8(8):e67057. https://doi.org/10.1371/journal.pone.0067057

66. KATO T, ITO T, IMATANI T, MINAGUCHI K, SAITOH E, OKUDA K 2004 Cystatin SA, a cysteine proteinase inhibitor, induces interferon-gamma expression in CD4-positive T cells. Biol Chem 385(5):419-22. https://doi.org/10.1515/BC.2004.047

67. LERTNAWAPAN R, BIAN A, RHO YH, RAGGI P, OESER A, et al. 2012 Cystatin $C$ is associated with inflammation but not atherosclerosis in systemic lupus erythematosus. Lupus 21(3):279-87. https://doi.org/10.1177/0961203311425527

68. ZHANG M, LI Y, YANG X, SHAN H, ZHANG Q, et al. 2016 Serum cystatin $\mathrm{C}$ as an inflammatory marker in exacerbated and convalescent COPD patients. Inflammation 39(2):625-31. https://doi.org/10.1007/s10753-015-0287-x

69. HASHIMOTO S, SUZUKI T, DONG HY, NAGAIS, YAMAZAKI N, MATSUSHIMA K 1999 Serial analysis of gene expression in human monocyte-derived dendritic cells. Blood 94(3):845-52

70. ZAVASNIK-BERGANT T, REPNIK U, SCHWEIGER A, ROMIH R, JERAS M, et al. 2005 Differentiation- and maturationdependent content, localization, and secretion of cystatin C in human dendritic cells. J Leukoc Biol 78(1):122-34. https://doi.org/10.1189/jlb.0804451

71. EL-SUKKARI D, WILSON NS, HAKANSSON K, STEPTOE RJ, GRUBB A, et al. 2003 The protease inhibitor cystatin C is differentially expressed among dendritic cell populations, but does not control antigen presentation. J Immunol 171(10):5003-11. https://doi.org/10.4049/jimmunol.171.10.5003

72. NI J, FERNANDEZ MA, DANIELSSON L, CHILLAKURU RA, ZHANG J, et al. 1998 Cystatin $\mathrm{F}$ is a glycosylated human low molecular weight cysteine proteinase inhibitor. J Biol Chem 273(38): 24797-804. https://doi.org/10.1074/jbc.273.38.24797 
73. HALFON S, FORD J, FOSTER J, DOWLING L, LUCIAN L, et al. 1998 Leukocystatin, a new class II cystatin expressed selectively by hematopoietic cells. J Biol Chem 273(26):16400-408. https://doi.org/10.1074/jbc.273.26.16400

74. OBATA-ONAI A, HASHIMOTO S, ONAI N, KURACHI M, NAGAI S, et al. 2002 Comprehensive gene expression analysis of human NK cells and CD8+ T lymphocytes. Int Immunol 14(10):1085-98. https://doi.org/10.1093/intimm/dxf086

75. NATHANSON C-M, WASSÉLIUS J, WALLIN H, ABRAHAMSON M 2002 Regulated expression and intracellular localization of cystatin F in human U937 cells. Eur J Biochem 269(22):5502-11. https://doi.org/10.1046/j.1432-1033.2002.03252.x

76. COLBERT JD, PLECHANOVOVÁ A, WATTS C 2009 Glycosylation directs targeting and activation of cystatin $\mathrm{F}$ from intracellular and extracellular sources. Traffic 10(4):425-37. https://doi.org/10.1111/j.1600-0854.2009.00881.x

77. LANGERHOLC T, ZAVASNIK-BERGANT V, TURK B, TURK V, ABRAHAMSON M, KOS J 2005 Inhibitory properties of cystatin $\mathrm{F}$ and its localization in U937 promonocyte cells. FEBS J 272(6):1535-45. https://doi.org/10.1111/j.1742-4658.2005.04594.x

78. HAMILTON G, COLBERT JD, SCHUETTELKOPF AW, WATTS C 2008 Cystatin F is a cathepsin C-directed protease inhibitor regulated by proteolysis. EMBO J 27(3):499-508. https://doi.org/10.1038/sj.emboj.7601979

79. MAGISTER S, OBERMAJER N, MIRKOVIĆ B, SVAJGER U, RENKO M, et al. 2012 Regulation of cathepsins $S$ and L by cystatin F during maturation of dendritic cells. Eur J Cell Biol 91(5):391401. https://doi.org/10.1016/j.ejcb.2012.01.001

80. MATTHEWS SP, MCMILLAN SJ, COLBERT JD, LAWRENCE RA, WATTS C 2016 Cystatin F ensures eosinophil survival by regulating granule biogenesis. Immunity 44(4):795-806. https://doi.org/10.1016/j.immuni.2016.03.003

81. TRAPANI JA, SMYTH MJ 2002 Functional significance of the perforin/granzyme cell death pathway. Nat Rev Immunol 2(10):73547. https://doi.org/10.1038/nri911

82. ANDERSEN MH, SCHRAMA D, THOR STRATEN P, BECKER JC 2006 Cytotoxic T cells. J Invest Dermatol 126(1):32-41. https://doi.org/10.1038/sj.jid.5700001

83. CHOWDHURY D, LIEBERMAN J 2008 Death by a thousand cuts: granzyme pathways of programmed cell death. Annu Rev Immunol 26:389-420.

https://doi.org/10.1146/annurev.immunol.26.021607.090404

84. VAN PARIJS L, ABBAS AK 1996 Role of Fas-mediated cell death in the regulation of immune responses. Curr. Opin. Immunol. 8(3):355-61. https://doi.org/10.1016/S0952-7915(96)80125-7

85. PAGE LJ, DARMON AJ, UELLNER R, GRIFFITHS GM 1998 $\mathrm{L}$ is for lytic granules: lysosomes that kill. Biochim Biophys Acta 1401(2):146-56. https://doi.org/10.1016/S0167-4889(97)00138-9

86. BLOTT EJ, GRIFFITHS GM 2002 Secretory lysosomes. Nat Rev Mol Cell Biol 3(2):122-31. https://doi.org/10.1038/nrm732

87. NANEH O, AVČIN T, BEDINA ZAVEC A 2014 Perforin and human diseases. Subcell Biochem 80:221-39. https://doi.org/10.1007/978-94-017-8881-6_11

88. UELLNER R, ZVELEBIL MJ, HOPKINS J, JONES J, MACDOUGALL LK, et al. 1997 Perforin is activated by a proteolytic cleavage during biosynthesis which reveals a phospholipid-binding C2 domain. EMBO J 16(24):7287-96. https://doi.org/10.1093/emboj/16.24.7287

89. VOSKOBOINIK I, WHISSTOCK JC, TRAPANI JA 2015 Perforin and granzymes: function, dysfunction and human pathology. Nat Rev Immunol 15(6):388-400. https://doi.org/10.1038/nri3839

90. VOSKOBOINIK I, SMYTH MJ, TRAPANI JA 2006 Perforinmediated target-cell death and immune homeostasis. Nat Rev Immunol 6(12):940-52. https://doi.org/10.1038/nri1983

91. GROSSMAN WJ, REVELL PA, LU ZH, JOHNSON H, BREDEMEYER AJ, LEY TJ 2003 The orphan granzymes of humans and mice. Curr Opin Immunol 15(5):544-52. https://doi.org/10.1016/S0952-7915(03)00099-2

92. ANTHONY DA, ANDREWS DM, WATT SV, TRAPANI JA, SMYTH MJ 2010 Functional dissection of the granzyme family: cell death and inflammation. Immunol Rev 235(1):73-92. https://doi.org/10.1111/j.0105-2896.2010.00907.x

93. MASSON D, TSCHOPP J 1987 A family of serine esterases in lytic granules of cytolytic T lymphocytes. Cell 49(5):679-85. https://doi.org/10.1016/0092-8674(87)90544-7

94. PHAM CT, LEY TJ 1999 Dipeptidyl peptidase I is required for the processing and activation of granzymes A and B in vivo. Proc Natl Acad Sci U S A 96(15):8627-32. https://doi.org/10.1073/pnas.96.15.8627

95. MANDAL A, VISWANATHAN C 2014 Natural killer cells: in health and disease. Hematol Oncol Stem Cell Ther 8(2):47-55. https://doi.org/10.1016/j.hemonc.2014.11.006

96. CALIGIURI MA 2008 Human natural killer cells. Blood 112(3): 461-69. https://doi.org/10.1182/blood-2007-09-077438

97. LANIER L. 200. Up on the tightrope: natural killer cell activation and inhibition. Nat Immunol 9(5):495-502. https://doi.org/10.1038/ni1581

98. GROSS E, SUNWOO JB, BUI JD 2013 Cancer immunosurveillance and immunoediting by natural killer cells. Cancer J 19(6):483-89. https://doi.org/10.1097/PPO.0000000000000005

99. SMYTH MJ, HAYAKAWA Y, TAKEDA K, YAGITA H 2002 New aspects of natural-killer-cell surveillance and therapy of cancer. Nat Rev Cancer 2(11):850-61. https://doi.org/10.1038/nrc928

100. ELAVAZHAGAN S, FATEHCHAND K, SANTHANAM V, FANG H, REN L, et al. 2015 Granzyme B expression is enhanced in human monocytes by TLR8 agonists and contributes to antibody-dependent cellular cytotoxicity. J Immunol 194(6):2786-95. https://doi.org/10.4049/jimmunol.1402316

101. BROERE F, APASOV S, SITKOVSKY M, VAN EDEN W 2011 A2 $\mathrm{T}$ cell subsets and T cell-mediated immunity. In: FP Nijkamp, MJ Parnham (ed) Principles of Immunopharmacology. Birkhäuser, Basel, p 15-27. https://doi.org/10.1007/978-3-0346-0136-8_2

102. DE LA ROCHE M, ASANO Y, GRIFFITHS GM 2016 Origins of the cytolytic synapse. Nat Rev Immunol 16(7):421-32. https://doi.org/10.1038/nri.2016.54

103. SÖDERBERG O, LEUCHOWIUS K-J, GULLBERG M, JARVIUS M, WEIBRECHT I, et al. 2008 Characterizing proteins and their interactions in cells and tissues using the in situ proximity ligation assay. Methods 45(3):227-32. https://doi.org/10.1016/j.ymeth.2008.06.014

104. MAGISTER Š, TSENG H-C, BUI VT, KOS J, JEWETT A 2015 Regulation of split anergy in natural killer cells by inhibition of cathepsins $\mathrm{C}$ and $\mathrm{H}$ and cystatin F. Oncotarget 6(26):22310-27. https://doi.org/10.18632/oncotarget.4208

105. JEWETT A, MAN Y, CACALANO N, KOS J, TSENG H-C 2014 Natural killer cells as effectors of selection and differentiation of stem cells: role in resolution of inflammation. J Immunotoxicol 11(4):297-307. https://doi.org/10.3109/1547691X.2013.877104

106. JEWETT A, BONAVIDA B 1995 Target-induced anergy of natural killer cytotoxic function is restricted to the NK-target conjugate subset. Cell Immunol 160(1):91-97. https://doi.org/10.1016/0008-8749(95)80013-9

107. CHAN C-B, ABE M, HASHIMOTO N, HAO C, WILLIAMS IR, et al. 2009 Mice lacking asparaginyl endopeptidase develop disorders resembling hemophagocytic syndrome. Proc Natl Acad Sci U S A 106(2):468-73. https://doi.org/10.1073/pnas.0809824105

108. COLBERT JD, MATTHEWS SP, KOS J, WATTS C 2011 Internalization of exogenous cystatin $F$ supresses cysteine proteases and induces the accumulation of single-chain cathepsin L by multiple mechanisms. J Biol Chem 286(49):42082-90. https://doi.org/10.1074/jbc.M111.253914 